\title{
Emission of gases from coal at low-temperature oxidation depending on the oxygen sorption rate
}

\author{
Vyacheslav Portola ${ }^{1}$, Alyona Bobrovnikova ${ }^{1}$, and Qiang Zeng ${ }^{2}$ \\ ${ }^{1}$ T.F. Gorbachev Kuzbass State Technical University, 650000, Russian Federation \\ ${ }^{2}$ Institute for Arid Ecology and Environment, Center for Underground Coal Fire, Xinjiang University \\ Add.: No.666 Shengli Road, Urumqi city 830091, Xinjiang region, China
}

\begin{abstract}
Coal oxidation by air oxygen can cause a process of spontaneous combustion with intense emission of carbon oxide and danger to initiate explosion of combustible gases. To detect the process of coal spontaneous combustion in mines, they use a gas analysis method providing control of concentrations of carbon oxide, hydrogen and hydrocarbons in the atmosphere. The conducted researches showed that at low-temperature oxidation of coal the intense emission of these gases without temperature increase is possible. Concentration of carbon oxide significantly increases with the growth of coal oxygen sorption rate. Ethylene and carbon dioxide show similar regularities. Acetylene is not found as a result of low-temperature oxidation of coal, and emission of hydrogen, methane, ethane, propane and propylene does not depend on the coal oxygen sorption rate.
\end{abstract}

\section{Introduction}

Coal mining is accompanied by a number of dangerous phenomena threatening health and life of a person. In coal mines the most dangerous phenomena can be an emission of combustible and toxic gases from coal capable to cause intoxication of miners and explosion of thecreated gas mix. Dangerous gases which were formed in the course of coal metamorphism are emitted at the stage of extraction out of the destroyed coalbed and enclosing rocks. Crushing of mineral is followed by breaking of bonds in coal molecules that promotes formation of volatile compounds of carbon and hydrogen. The main share of gases emitted at coal mining are combustible and dangerous because of a possibility of formation of explosive mixtures and decrease in concentration of oxygen.

At the following stage there is an oxidation of coal extracted and lost in mine by air oxygen. Sorption and chemical interaction of coal components and oxygen result in heat release. Therefore,the coal oxidation under favourable conditions for heat exchange with the environment can lead to spontaneous combustion of coal accumulations. The process of coal spontaneous combustion in mine is followed by emission of such toxic gas as carbon oxide, and also lowering of concentration of oxygen in the underground air. The formed source of combustion can initiate explosion of combustible gases. Spontaneous combustion is also dangerous on the ground surface because of release of dangerous gases [1]. Research 
of the coal spontaneous combustion process [2-9] allowed revealing conditions necessary for forming of sources of endogenous fires.

Complexity of fight against endogenous fires in mines is caused by the fact that the spontaneous combustion process often appears in a mined-out area that complicates detection of a fire source at the early stage of development and its suppression. Considering danger of the spontaneous combustion process in mines, different ways of detection of the sources are offered, using the products which are formed at increase of coal temperature [10-20]. Usually to detect coal spontaneous combustion sources, the gases emitted at oxidation and thermal destruction of coal are used. In certain cases other components can be indicators of spontaneous combustion. So, to detect the spontaneous combustion process, it is offered to use radon emitted from coal $[12,13]$ and also water particles condensed in the air which has passed through a warmed accumulation of coal [14].

The most widespread way of detection of coal spontaneous combustion processes in mines is the gas analysis method providing control of composition of the underground air. The main indicator gas of the coal spontaneous combustion process in mines is carbon oxide which concentration is continuously or periodically measured by portable or fixed instruments in the course of mining of coalbeds prone to spontaneous combustion. Increase of concentration of such indicator fire gases as hydrogen, carbon dioxide, saturated and unsaturated hydrocarbons is considered to be an additional sign of spontaneous combustion.

Emergence in the underground air of such gases from coal oxidation at a natural rock temperaturecomplicates detection of coal spontaneous combustion sources at the initial stage of development. Therefore, it is necessary to investigate features of formation of indicator fire gases at the stage of low-temperature oxidation of coal by oxygen of the underground air. Determination of patterns of change in release of different gases at the low-temperature stage will allow increasing efficiency of detection of spontaneous combustion sources by the gas analysis method.

\section{Results of the research}

In order to detect features of emission of indicator fire gases at low-temperature oxidation, the coal samples from different mines of Kuzbasswere used. Experiments were made with coal of the following beds: Bezymyannyj, SychevskijIV, GramoteinskijII, No.50, No.66, No.3, No.26a, No.15, No.7-7a, E-5., etc. The coal samples were crushed in laboratory to fractions 1-3 mm. Then the coal samples were placed in sorption vessels, closed hermetically and maintained at a constant temperature $\left(24^{\circ} \mathrm{C}\right)$. In 24 hours the air from vessels was sampled for determination of concentrations of oxygen, carbon dioxide, carbon oxide, hydrogen, methane, ethane, ethylene, propane, propylene and acetylene.

Chemical activity of coal in relation to the air oxygen was estimated according to the oxygen sorption rate of the coal samples. The coal oxygen sorption rate, equal to the volume of oxygen absorbed by 1 gram of coal during 1 hour at $100 \%$ concentration of oxygen in surrounding volume, was calculated using a formula:

$$
K=-\frac{V}{M \tau} \ln \frac{C_{A}\left(100-C_{0}\right)}{C_{0}\left(100-C_{A}\right)}
$$

where $\mathrm{V}$ - air volume which is in contact with coal, $\mathrm{cm}^{3} ; \mathrm{M}$ - mass of the coal sample, $\mathrm{g}$; $\tau$ - time of contact of air and coal, h; Co - initial concentration of oxygen in the vessel, $\%$.; $\mathrm{C}_{\mathrm{A}}$ - concentration of oxygen after time $\tau, \%$.

Results of the gas composition measurement and calculation of the coal oxygen sorption rate after 24 hours of maintenance are given in Table 1. Acetylene was not found at lowtemperature oxidation of coal in all experiments, therefore it is not included in the table. 
Table 1. Concentration of gases emitted from coal and the oxygen sorption rate at low-temperature oxidation

\begin{tabular}{|c|c|c|c|c|c|c|c|c|c|}
\hline \multirow[t]{2}{*}{ Coalbed } & \multirow{2}{*}{$\begin{array}{c}\mathbf{K}, \\
\mathrm{cm}^{3} /(\mathrm{g} \cdot \mathbf{h} \\
)\end{array}$} & \multicolumn{8}{|c|}{ Gas concentration, \% (vol.) } \\
\hline & & $\begin{array}{c}\mathrm{CO} \\
2\end{array}$ & $\mathrm{CO}$ & $\mathbf{H}_{2}$ & $\mathrm{CH}_{4}$ & $\mathrm{C}_{2} \mathrm{H}_{6}$ & $\mathrm{C}_{2} \mathrm{H}_{4}$ & $\mathrm{C}_{3} \mathrm{H}_{8}$ & $\mathrm{C}_{3} \mathrm{H}_{6}$ \\
\hline $7-7 \mathrm{a}$ & 0.0365 & $\begin{array}{l}0.2 \\
3\end{array}$ & $\begin{array}{l}0.006 \\
5\end{array}$ & $\begin{array}{l}0.000 \\
3\end{array}$ & 7.65 & $\begin{array}{l}0.028 \\
9\end{array}$ & $\begin{array}{l}0.0000 \\
5\end{array}$ & $\begin{array}{l}0.0000 \\
9\end{array}$ & 0 \\
\hline 3 & 0.0404 & $\begin{array}{l}0.2 \\
4\end{array}$ & 0.007 & $\begin{array}{l}0.000 \\
4\end{array}$ & 4.00 & $\begin{array}{l}0.003 \\
5\end{array}$ & 0 & $\begin{array}{l}0.0000 \\
1\end{array}$ & $\begin{array}{l}0.0000 \\
1\end{array}$ \\
\hline $26 a$ & 0.0429 & $\begin{array}{l}0.2 \\
8\end{array}$ & $\begin{array}{l}0.012 \\
3\end{array}$ & 0 & $\begin{array}{l}10.5 \\
5\end{array}$ & $\begin{array}{l}0.018 \\
1\end{array}$ & $\begin{array}{l}0.0000 \\
9\end{array}$ & 0.0018 & 0 \\
\hline $26 a$ & 0.0433 & $\begin{array}{l}0.1 \\
5\end{array}$ & $\begin{array}{l}0.007 \\
6\end{array}$ & $\begin{array}{l}0.000 \\
2\end{array}$ & $\begin{array}{l}15.6 \\
1\end{array}$ & $\begin{array}{l}0.392 \\
6\end{array}$ & $\begin{array}{l}0.0000 \\
5\end{array}$ & 0.1552 & 0 \\
\hline 50 & 0.0640 & $\begin{array}{l}0.8 \\
7\end{array}$ & $\begin{array}{l}0.012 \\
7\end{array}$ & $\begin{array}{l}0.000 \\
4\end{array}$ & 5.86 & $\begin{array}{l}0.016 \\
1\end{array}$ & $\begin{array}{l}0.0000 \\
6\end{array}$ & $\begin{array}{l}0.0001 \\
3\end{array}$ & $\begin{array}{l}0.0000 \\
1\end{array}$ \\
\hline 15 & 0.0697 & $\begin{array}{l}0.3 \\
7\end{array}$ & $\begin{array}{l}0.008 \\
4\end{array}$ & $\begin{array}{l}0.000 \\
3\end{array}$ & 7.45 & $\begin{array}{l}0.080 \\
4\end{array}$ & $\begin{array}{l}0.0000 \\
6\end{array}$ & 0.0042 & 0 \\
\hline E-5 & 0.0903 & $\begin{array}{l}0.1 \\
6\end{array}$ & $\begin{array}{l}0.015 \\
2\end{array}$ & $\begin{array}{l}0.000 \\
5\end{array}$ & $\begin{array}{l}14.9 \\
7\end{array}$ & $\begin{array}{l}0.066 \\
3\end{array}$ & 0 & $\begin{array}{l}0.0137 \\
3\end{array}$ & 0 \\
\hline SychevskijIV & 0.1131 & $\begin{array}{l}0.3 \\
0\end{array}$ & $\begin{array}{l}0.068 \\
8\end{array}$ & 0 & 7.53 & $\begin{array}{l}0.001 \\
2\end{array}$ & $\begin{array}{l}0.0000 \\
9\end{array}$ & $\begin{array}{l}0.0005 \\
6\end{array}$ & 0 \\
\hline SychevskijIV & 0.1349 & $\begin{array}{l}0.4 \\
1\end{array}$ & $\begin{array}{l}0.021 \\
0\end{array}$ & $\begin{array}{l}0.000 \\
8\end{array}$ & 18.5 & $\begin{array}{l}0.116 \\
6\end{array}$ & $\begin{array}{l}0.0002 \\
6\end{array}$ & $\begin{array}{l}0.0176 \\
2\end{array}$ & 0 \\
\hline $\begin{array}{l}\text { Gramoteinski } \\
\text { j }\end{array}$ & 0.1351 & $\begin{array}{l}0.2 \\
9\end{array}$ & $\begin{array}{l}0.070 \\
7\end{array}$ & $\begin{array}{l}0.000 \\
4\end{array}$ & 1.36 & $\begin{array}{l}0.000 \\
7\end{array}$ & 0.0001 & $\begin{array}{l}0.0000 \\
4\end{array}$ & $\begin{array}{l}0.0000 \\
1\end{array}$ \\
\hline 66 & 0.1407 & $\begin{array}{l}0.8 \\
6\end{array}$ & $\begin{array}{l}0.021 \\
1\end{array}$ & 0 & 4.55 & $\begin{array}{l}0.000 \\
5\end{array}$ & 0.0002 & $\begin{array}{l}0.0001 \\
8\end{array}$ & 0 \\
\hline $\begin{array}{l}\text { Bezymyanny } \\
\mathrm{j}\end{array}$ & 0.1730 & $\begin{array}{l}0.2 \\
1\end{array}$ & $\begin{array}{l}0.036 \\
2\end{array}$ & $\begin{array}{l}0.000 \\
8\end{array}$ & $\begin{array}{l}17.5 \\
1\end{array}$ & $\begin{array}{l}0.001 \\
6\end{array}$ & 0.0002 & $\begin{array}{l}0.0000 \\
7\end{array}$ & $\begin{array}{l}0.0000 \\
1\end{array}$ \\
\hline SychevskijIV & 0.2354 & $\begin{array}{l}0.3 \\
5\end{array}$ & $\begin{array}{l}0.052 \\
4\end{array}$ & $\begin{array}{l}0.000 \\
4\end{array}$ & $\begin{array}{l}22.6 \\
9\end{array}$ & $\begin{array}{l}0.064 \\
2\end{array}$ & 0.0004 & $\begin{array}{l}0.0000 \\
9\end{array}$ & $\begin{array}{l}0.0000 \\
5\end{array}$ \\
\hline
\end{tabular}

An analysis of the obtained data shows that at low-temperature oxidation coal emits toxic and combustible gases, and concentration of carbon oxide at a coal surface in an airless zone can reach $1 / 100$ th of a percent. Such content of carbon oxide is capable to cause chronic intoxication of people and be classified as a coal self-heating.

Evaluating the oxygen sorption rate, it is necessary to notice that activity of coal of one bed can significantly change in different points of sampling. So, the chemical activity of coal from the SychevskijIV coalbed changes more than twice. Therefore, the duration of incubatory period for spontaneous combustion can change considerably in different mined areas. Respectively, coal in nearby located mines and even different faces can be prone or not prone to spontaneous combustion.

According to the results of the researches, it is possible to note that carbon oxide emission depends on the coal oxygen sorption rate given on Fig. 1.

Analysing the provided data, it is possible to draw a conclusion that with increase in chemical activity of coal there is a growth of carbon oxide concentration in the ambient air without temperature increase. Single deviations from the received dependence can be caused by the increased initial content of carbon oxide in coal. Thus, it is possible to conclude that for the studied coals of Kuzbass a basic reason for carbon oxide emission at a 
natural rock temperature is the process of coal oxidation by oxygen. And the concentration of carbon oxide can differ by 5-10 times in different coalbeds without formation of selfheating sources.

Change of concentration of carbon dioxide depending on the coal oxygen sorption rateis given in Fig. 2. The provided results show that initially coal has high content of carbon dioxide which can significantly change in different beds. However, with increase in chemical activity of coal the tendency of increase in carbon dioxide emission is observed.

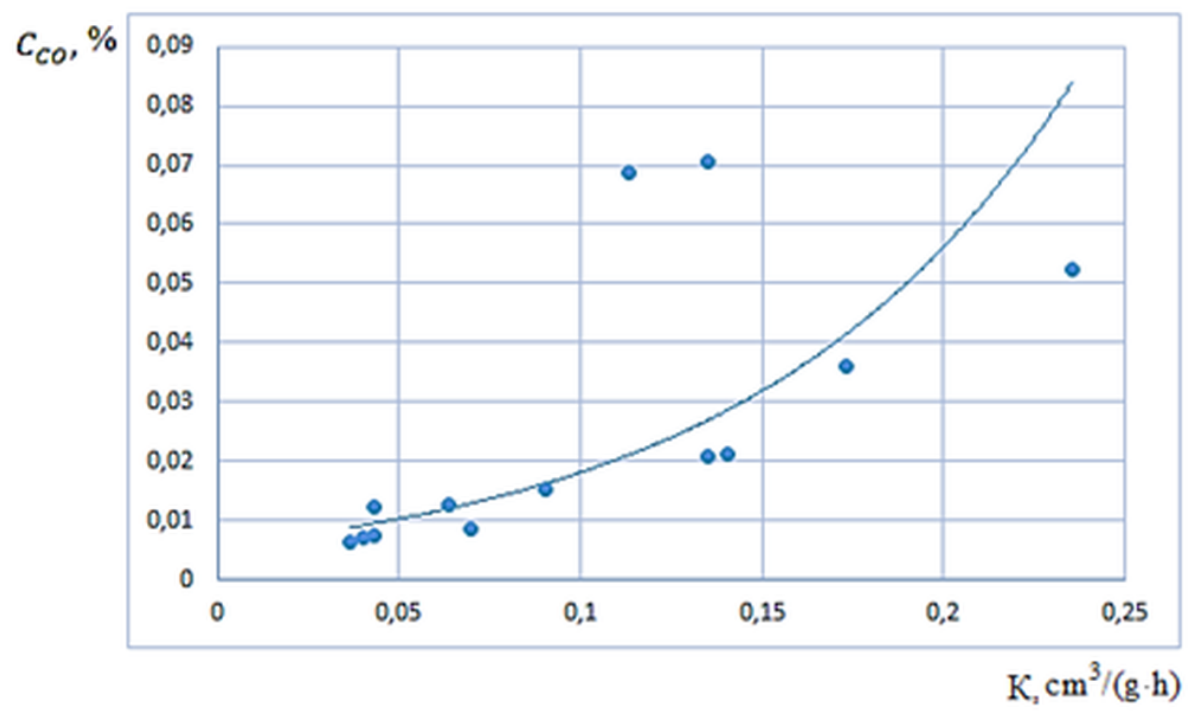

Fig. 1. Influence of coal chemical activity in relation to oxygen on carbon oxide emission

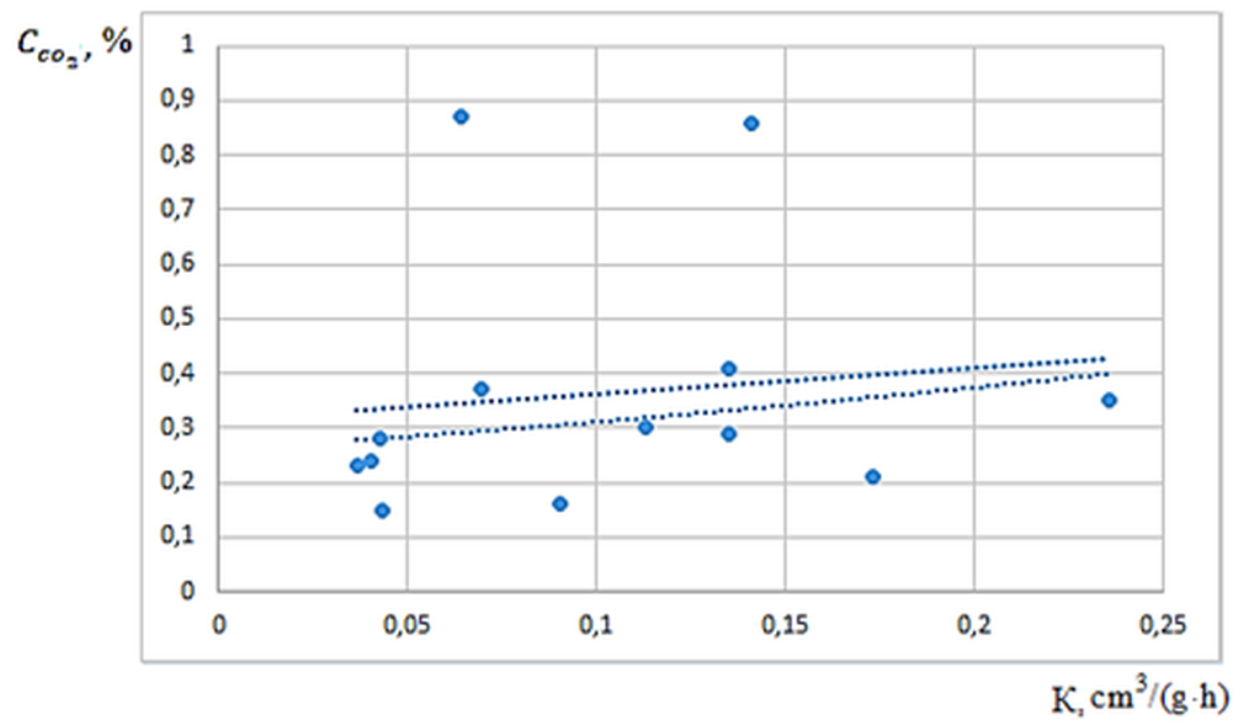

Fig. 2. Carbon dioxide emission depending on chemical activity of coal to oxygen 
As a part of the study the influence of the coal oxygen sorption rate on methane emission and also the influence of saturated and unsaturated hydrocarbons were assessed. As the result of the experiment the dependence of ethylene emission on the coal oxygen sorption rate constant was found. The general tendency of increase in concentration of ethylene with the growth of chemical activity of coal (Fig. 3) is observed. The emission of hydrogen, methane, ethane, propane and propylene at low-temperature oxidation of coal occurs in a wide range, has a random character and does not depend on the oxygen sorption rate.

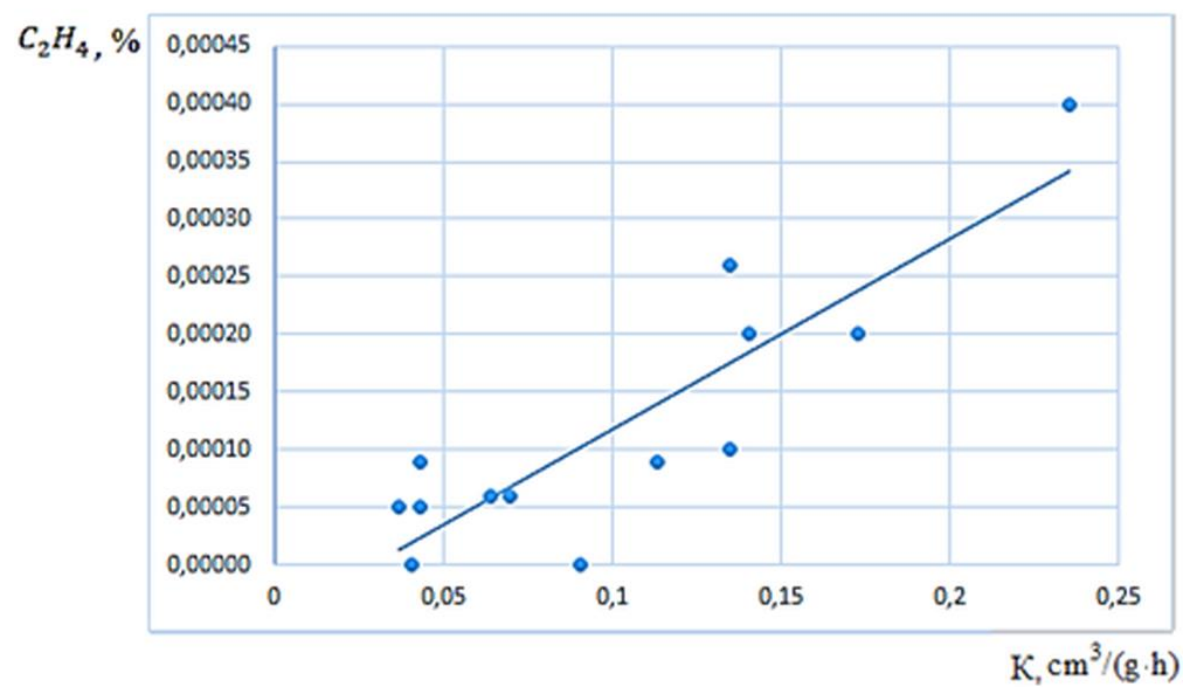

Fig. 3. Ethylene emission depending on chemical activity of coal to oxygen

Basing on the research findings the specific intensity of gas emission from coal at lowtemperature oxidation was also defined. The specific intensity of gas emission was calculated using a formula:

$$
Q=-\frac{V\left(C_{\Gamma}-C\right)}{100 M \tau}
$$

where Q - specific intensity of gas emission, $\mathrm{cm}^{3} /(\mathrm{g} \cdot \mathrm{h}) ; \mathrm{C}_{\Gamma}$ - concentration of the emitted gas, $\%$.

The calculation did not consider the methane emission in the atmosphere, which does not depend on the coal chemical activity to oxygen but is defined by the initial content in coal. The calculation results are given in Table 2.

Table 2. Specific intensity of gas emission from coal at low-temperature oxidation

\begin{tabular}{|c|c|c|c|c|c|c|c|c|}
\hline \multirow[t]{2}{*}{ Coalbed } & \multirow{2}{*}{$\begin{array}{c}\mathrm{K}, \\
\mathrm{cm}^{3} /(\mathrm{g} \cdot \mathbf{h})\end{array}$} & \multicolumn{7}{|c|}{ Specific intensity of gas emission, $Q \cdot 10^{5}, \mathrm{~cm}^{3} /(\mathrm{g} \cdot \mathrm{h})$} \\
\hline & & $\mathrm{CO}_{2}$ & CO & $\mathbf{H}_{2}$ & $\mathrm{C}_{2} \mathrm{H}_{6}$ & $\mathrm{C}_{2} \mathrm{H}_{4}$ & $\mathrm{C}_{3} \mathrm{H}_{8}$ & $\mathrm{C}_{3} \mathrm{H}_{6}$ \\
\hline $7-7 \mathrm{a}$ & 0.0365 & 68.08 & 1.924 & 0.088 & 8.554 & 0.0148 & 0.0266 & 0.0000 \\
\hline 3 & 0.0404 & 71.04 & 2.070 & 0.118 & 1.036 & 0.0000 & 0.0030 & 0.0030 \\
\hline $26 \mathrm{a}$ & 0.0429 & 82.88 & 3.640 & 0.000 & 5.357 & 0.0266 & 0.5330 & 0.0000 \\
\hline $26 \mathrm{a}$ & 0.0433 & 44.40 & 2.249 & 0.059 & 116.2 & 0.0148 & 45.940 & 0.0000 \\
\hline 50 & 0.0640 & 257.5 & 3.759 & 0.118 & 4.780 & 0.0177 & 0.0380 & 0.0030 \\
\hline
\end{tabular}




\begin{tabular}{|l|l|l|l|l|l|l|l|l|}
\hline 15 & 0.0697 & 109.5 & 2.486 & 0.088 & 23.79 & 0.0187 & 1.2430 & 0.0000 \\
\hline E-5 & 0.0903 & 47.36 & 4.499 & 0.148 & 19.63 & 0.0000 & 4.0640 & 0.0000 \\
\hline Sych.IV & 0.1131 & 88.80 & 20.36 & 0.000 & 0.352 & 0.0260 & 0.1660 & 0.0000 \\
\hline Sych.IV & 0.1349 & 121.3 & 6.216 & 0.237 & 34.51 & 0.0760 & 5.2150 & 0.0000 \\
\hline Gram. & 0.1351 & 85.84 & 20.92 & 0.118 & 0.207 & 0.0296 & 0.0118 & 0.0030 \\
\hline 66 & 0.1407 & 254.5 & 6.245 & 0.000 & 0.148 & 0.5920 & 0.0533 & 0.0000 \\
\hline Bezym. & 0.1730 & 62.16 & 10.71 & 0.237 & 0.540 & 0.0620 & 0.0200 & 0.0030 \\
\hline Sych.IV & 0.2354 & 103.6 & 15.51 & 0.1184 & 19.00 & 0.1300 & 0.0266 & 0.0148 \\
\hline
\end{tabular}

An analysis of the results given in Table 2 shows that carbon dioxide has the most intense emission at low-temperature oxidation of coal. Despite the wide range of intensity of the carbon dioxide emission, the tendency of increase in its release into the air at the growth of coal chemical activity is observed. Ethane takes the second place for emission intensity at low-temperature oxidation of coal. Intensity of carbon oxide emission is comparable to the ethane emission. The fourth place for emission intensity is taken by propane.

\section{Conclusions}

On the basis of the conducted research it is possible to draw the following conclusions.

1. At low-temperature oxidation of coal the increase in the coal oxygen sorption rate leads to the essential growth of carbon oxide emission into the atmosphere that can be mistakenly treated as development of thespontaneous combustion process.

2. Emission of ethylene and carbon dioxide at low-temperature oxidation happens in the wide range with the general tendency of growth of gas emission at increase of the coal oxygen sorption rate that also complicates use of these gases as indicators of the spontaneous combustion process at the early stage of development.

3. Intensity of emission of hydrogen, ethane and propane at low-temperature oxidation can change in the wide range depending on initial properties of coal that does not allow to find the dependence of their concentration on the coal oxygen sorption rate.

4. Considering possibility of essential increase in concentration of indicator fire gases in the underground air at low-temperature oxidation of coal in mine, it is necessary to preliminary investigate the coal of each mined site for determination of possible concentrations of these gases at a rock temperature. The increased contents in the underground air of such indicator fire gases as carbon oxide, ethylene without a spontaneous combustion source may be predicted at the stage of definition of the coal oxygen sorption rate.

\section{References}

1. S.S. Timofeeva, P. Yankova, S.S. Timofeev, N.Y. Lugovtsova, Assessing the unaccounted environmental pressure caused by endogenous fires on the rock dumps of Kuzbass. IOP Conference Series: Earth and Environmental Science, Current Problems and Solutions, 012057 (2019)

2. Q. Lin, S. Wang, S. Song, Y. Liang, T. Ren, Fuel Processing Technology 159, 38 (2017)

3. V.A. Portola, Journal of Mining Science, 32:6, 536 (1996) 
4. S. Wessling,; W. Kessels,; M. Schmidt, U. Krause, Geophysical Journal International. 172, 439 (2008)

5. Xiao Y., LiQ.-W., Deng J., Shu C.-M., Wang W., .Experimental study on the corresponding relationship between the index gases and critical temperature for coal spontaneous combustion. J. Therm. Anal. Calorim, 127, 1009 (2017)

6. Avila C., Tao W., Lester E., Energy Fuels, 28, 1765 (2014)

7. Zhang Y., Liu Y., Shi X., Yang C., Wang W., Li Y., Fuel, 233, 68 (2018)

8. Deng J., Zhao, J.-Y., Zhang, Y.-N., Wang, C.-P., Huang, A.-C., Shu, C.-M., Journal of Thermal Analysis\&amp. 127:1, 439 (2017)

9. R. Chakravorty, and R. Kolada, Prevention and Control of Spontaneous Combustion in Coal Mines, Mining Engineering, 952 (1988)

10. Wang J., Zhang Y., Xue S., Wu J., Tang Y., Chang L., Fuel Process, Technol., 179, 60 (2018)

11. Shao Z., Jia X., Zhong X., Wang D., Wei J., Wang Y., Chen L., Sci. Pollut. Res., 25, 26603 (2018)

12. V.A. Portola, E.S. Torosyan, V.K. Antufeyev, Radon Emission from Coal Mines of Kuzbass Region, IOP Conference Series: Materials Science and Engineering, Urgent Problems of Modern Mechanical Engineering, 127, 012021 (2016)

13. Xue, S.; Dickson, B.; Wu, J. International Journal of Coal Geology, 74:2, 139 (2008)

14. V. Portola, A. Bobrovnikova, A. Shirokolobova, E3S Web of Conference, 105, 01037 (2019)

15. Li J., Li Z., Yang Y., Wang C., Fuel, 233, 237 (2018)

16. Dang J., Yu H., Zheng C., Wang Y., Sun Y. An early fire sensor based on infrared gas analytical methods. Anal. Methods-Uk 3325 (2018)

17. Dang J., Yu H., Song F., Wang Y., Sun Y., Zheng C. An early fire gas sensor based on $2.33 \mu \mathrm{m}$ DFB laser, Infrared Phys. Technol., 92, 84 (2018)

18. A. K. Singh,; , R. V. K. Singh., Singh, M. P.; Chandra, H.; Shuka, N. K., Journal of Coal Geology, 69:3, 192 (2007)

19. Xie, J.; Xue, S.; Cheng, W. M.; Wang, G., International Journal of Coal Geology, 85:1 $123(2011)$

20. R. Agarwal, D. Singh, D. S. Chauhan, K. P. Singh, Journal of Geophysics and Engineering, 3, 212 (2006) 